\title{
The basic function of happiness and vivacity from Rumi's point of view
}

\section{La función básica de la felicidad y la vivacidad desde el punto de vista de Rumi}

\author{
Ali Asghar Dalili Saleh
}

PhD student in Persian Language and Literature, Islamic Azad University, Mashhad Branch, Iran

\section{Mohammad Shah Badizadeh}

Member of the Department of Persian Language and Literature, Islamic Azad University, Mashhad Branch, Iran

*Correspondence

Email: AliAsgharDaliliSaleh@gmail.com

\section{Cite as:}

Dalili Saleh, A., \& Badizadeh, M. (2021). The basic function of happiness and vivacity from Rumi's point of view. Propósitos y Representaciones, 9(SPE3), e1110. Doi: http://dx.doi.org/10.20511/pyr2021.v9nSPE3.1110 


\begin{abstract}
Happiness is one of the effective characteristics in human existence that the human soul and body have received many effects from this emotional aspect of human beings. Although psychologists' definitions of the causes and factors of happiness are different, but everyone agrees on one basis, and that is the essential need of the individual and society to strengthen the dimension of happiness and vitality in human beings, and that this feature can lead to prosperity and growth. Provide progress in the individual and society. This article confirms that the teachings of Jalaluddin Mohammad Rumi seek to provide a bed of happiness, with the difference that happiness is different from the view of Rumi as a religious mystic with the views of other greats. This research intends to study happiness and vitality on the basis of spiritual Masnavi. Access to Rumi's thoughts and ideas is important because his ideas can be considered as a great Muslim poet and mystic and a representative of Islamic mysticism and can be generalized to the thoughts of many of his followers. Our method in this paper is a library based on documentary study and content analysis. According to Rumi, sorrow is one of the means of conduct and the seeker can not be painless and sorrow, and sorrow that is not in the path of growth is unpleasant and sorrow that is in the direction of excellence is valuable and pleasant. Sadness and happiness cause human mental moderation. Wise sorrows should be welcomed and irrational joys should be avoided. Wise sorrows are the path to happiness, and as a result, the dynamism and mobility of the soul destroys many of the sorrows and daily joys and gives true clarity to the human soul.
\end{abstract}

Keywords: Happiness, Spiritual Masnavi, Divan Shams, Rumi, Rumi, Neshat

\title{
Resumen
}

La felicidad es una de las características efectivas en la existencia humana que el alma y el cuerpo humanos han recibido muchos efectos de este aspecto emocional de los seres humanos. Aunque las definiciones de los psicólogos de las causas y factores de la felicidad son diferentes, todos están de acuerdo en una base, y esa es la necesidad esencial del individuo y la sociedad de fortalecer la dimensión de la felicidad y la vitalidad en los seres humanos, y que esta característica puede conducir a la prosperidad y el crecimiento. Proporcionar progreso en el individuo y la sociedad. Este artículo confirma que las enseñanzas de Jalaluddin Mohammad Rumi buscan brindar un lecho de felicidad, con la diferencia de que la felicidad es diferente de la visión de Rumi como un místico religioso con la visión de otros grandes. Esta investigación tiene como objetivo estudiar la felicidad y la vitalidad sobre la base del Masnavi espiritual. El acceso a los pensamientos e ideas de Rumi es importante porque sus ideas pueden ser consideradas como un gran poeta y místico musulmán y un representante del misticismo islámico y pueden generalizarse a los pensamientos de muchos de sus seguidores. Nuestro método en este artículo es una biblioteca basada en el estudio documental y el análisis de contenido. Según Rumi, el dolor es uno de los medios de conducta y el buscador no puede ser indoloro y el dolor, y el dolor que no está en el camino del crecimiento es desagradable y el dolor que está en la dirección de la excelencia es valioso y agradable. La tristeza y la felicidad causan moderación mental humana. Los dolores sabios deben ser bienvenidos y deben evitarse las alegrías irracionales. Los dolores sabios son el camino a la felicidad, y como resultado, el dinamismo y la movilidad del alma destruyen muchos de los dolores y alegrías diarias y dan verdadera claridad al alma humana.

Palabras clave: Felicidad, Masnavi espiritual, Divan Shams, Rumi, Rumi, Neshat

\section{Introduction}

Happiness and joy, as opposed to sorrow and grief, is a natural phenomenon that is always associated with human beings and intertwined with human life. Happiness arises from achieving something desirable and sorrow from the lack of something desirable in a person. Happiness is 
constantly accompanied by satisfaction and contentment of the soul, and sadness is accompanied by dissatisfaction and sorrow. Everyone's happiness depends on the breadth and depth of their vision. It is possible for two people to live in the same natural and external conditions, but one is drowning in the height of happiness and the other in the depths of sorrow. In this regard, the sorrow and joy of the common people of the society is fundamentally different from the sorrow and joy of the saints and the ambitious and virtuous human beings. Maulana Jalaluddin Mohammad Balkhi has a joyful and cheerful personality and is alien to sorrow and does not know sorrow. According to Maulana, eternal joy and happiness must arise from within man, and apparent joys will not last. For the joy which befalls man from without is, in the end, nothingness and destruction, which soon gives way to sorrow; But the joy that arises from within man leaves no room for sorrow and boredom. As Rumi said:

The words of the creators are ridiculous thoughts that cause fatigue and sorrow

(Rumi, 1389: 2/3559)

Maulana Jalaluddin Mohammad Balkhi is a terrifying poet and love, passion, joy and cheerfulness are an integral part of the essence and truth of this mystic poet and sorrow has no place in his dictionary of thought. In this article, the functions of Rumi's joy and excitement in his valuable work - the spiritual Masnavi - which is a full-fledged mirror of Rumi's pure mysticism and his joyful worldview are discussed.

\section{The concept of happiness}

Happiness in the word means happiness, bliss, happiness, joy, cheerfulness, tarab, artia, ecstasy, expansion, joy, joy, happiness, comfort and in the face of sorrow and grief. (Dehkhoda, under the word happiness). And in the term, happiness is a mental state of happiness and joy, which is defined by other people as pleasant or positive emotions from happiness to great joy. (See Matthews, 2007: 18). Happiness is "an emotional state and different from instincts and emotions due to being non-dynamic" (Hadfield, 1374: 145) and is one of the needs of contemporary man who suffers from the difficulties of life in the modern machine world. Today's man has realized that his absolutism is wrong about the desirability of living in this advanced world. Living in such a world has resulted in ease and well-being for contemporary man; But inevitably, he has also faced difficulties that threaten his mental health; So it is natural to look for ways to overcome sadness and understand happiness. Undoubtedly, happiness has a significant role in achieving success (see: Mirshah Jafari and others, 1381: 50; Ghasemi and Qureshian, 1388: 99-102).

Rumi is a poignant poet and love, passion and happiness are an integral part of the essence and truth of this mystic poet and sorrow has no entry in his dictionary. In this article, the functions of Rumi's joy and excitement in his valuable work - the spiritual Masnavi - which is a fullfledged mirror of Rumi's pure mysticism and his joyful worldview are discussed.

The roots of happiness in Masnavi

According to Rumi, the requirement for achieving true happiness and inner vitality is to know the causes and factors of sorrow in material life, which is rooted in the unbridled institution and instincts of man. The effect of sorrow and grief in man may be seen in the form of weeping and lamentation, which is a sign of distance from God and the involvement of the human heart and soul in carnal desires and aspirations. And also these same sorrows may arise in the hearts by the command of God. "When a mystic sees the sign of sorrow in himself, he should consider it as a sign of distance from the truth and cry for forgiveness and supplication, because sorrow and happiness also work for the truth in human beings, and where there is the will and the sign of the truth, The same sorrow turns into joy, and what is considered an obstacle and adherence, $\mathrm{m}$ "It becomes liberation and liberty."

If the fire of nature gives joy, Andrew gives joy to the king of religion 
Because your sorrow is asking for forgiveness, work for the Creator

(Rumi, 1389: 1 / 836-835)

One of the deepest human problems in today's society is the grief and depression that many people suffer from today, which has caused many depressed people to be hospitalized or commit suicide, but what is the reason for this? Rumi has a simple answer to the question. He says that these sorrows, like a sickle, reap our lives. The temptations, the narcissism, the selfishness and the winds of this self-construction and the pride of this false self of ours arise from ignorance. If we had known, we would never have given our heart to the unstable world, which is like a deceptive mirage, to grieve over it. (See Mathematics, 2006: 84). One of the most central factors of happiness in Rumi's view is the avoidance of selfishness. Perhaps nothing is as degrading and emotionally painful as human selfishness. Another factor in happiness is avoiding unattainable and unreasonable desires. "Therefore, the cause of all human troubles and suffering is attachment and dependence on other than God" (Mathematics, 1979: 38)

Man was helpless and poor, safe from the calamity of a greedy soul

That sorrow came to the greedy beggars who were accustomed to it

(Rumi, 1389: 3 / 3283-3282)

"In Rumi's view, grief is caused by belonging to something lost and lost, and the joy of hanging on to what has been achieved occurs." (Kaymanesh, 1366: 743).

The concept and nature of happiness in Masnavi

Rumi's works are a full-fledged mirror of his pure mysticism and exhilarating worldview. Rumi has a happy and reckless personality and Qalandarvar is happy and happiness is one of the prominent characteristics of Qalandars through the truth. And cheerfulness, passion, love and happiness are the characteristics of this great poet and mystic. There is no sadness in his dictionary. His incalculable passion and drunkenness brings every sorrow to you and invites you to listen and dance in your lover's dormitory. Describing his romantic ideology and profession, he says:

Until in my heart the face of that envy is full of joy, who is I in the whole world ?!

God, I do not know except sadness, I hear sorrow, but I do not know what!

(Rumi, 1345: 312)

Rumi's mystical passion and joy can not be considered as one of those fleeting and unstable states that arise in simple and superficial ecstasy; His philosophy of passion is rooted in the depths of his lofty thoughts and ideas and is based on his worldview about man and the world. (See Jafari, 1379: 106) The joy and vivacity that Rumi speaks of is not limited to a specific time and place, but is rooted in homelessness and timelessness.

So it means to go as far as possible that happiness is out of place and time

(Rumi, 1389: 3752: 6)

Farah bin Farah

Maulana Jalaluddin Mohammad Balkhi considers himself Farah bin Farah. "Rumi, who has burned the past and the future and beheaded the next day of credit, has risen from the hour and the day, and has become the son of time and time. "He, whose life is in weddings and Eid and 
renewal and continuous transition, where does he allow the tears of boredom to remain in his heart?" (Soroush, 2001: 253)

The phrase "Telvins" has risen from the clock

Because you left at one o'clock, because you are not a Muharram

(Rumi, 1389: 3 / 1556-1557)

It is time to fall into the trap of falling from the pests of happiness. Rumi considers one of the causes of sorrow to be in this trap and states reprehensibly that:

Fire a woman to both of you until you are full of knots of these two

(Rumi, 1389: 2/2201)

Rumi's poetry, after many centuries, still excites people with its musical song and makes it dance, clap, clap and cheer. What is this mystical enthusiasm and this spiritual ecstasy that after many years, passing through the dark houses of time and place, has reached today with the praiseworthy freshness that I still sing those words, in the longing of the beloved:

What a wedding is in the soul, on which the world of Zangqsh, on which the two hands of the young Russians and the artist are full

(Rumi, 1345: 25)

The secret of Rumi's happiness

To answer this question, we will consider some phrases from Shams' articles and then analyze the subject. Criticizing the despairing and monopolistic philosophical ideas, Shams Tabrizi says: "Shams is the direction of God's light, the philosopher left above the seven heavens, between space and vacuum, the philosopher says that the minds are ten and enclose all possibilities, how to deceive the vast universe of God Shams believes that: "The universe is very large and wide. You lied that this is what my mind perceives. In the world of inner mysteries, there are suns, months, stars. There is good news inside me. I am amazed at these people who rejoiced without the good news. If you put each one on a golden crown, you should not be satisfied with what we do. "We need to be open-minded." (Movahed, 1379: 179). The fruit of this openness, evangelism, joy, and bliss that ripples through the whole of the sun's longing is the infinite joy and enchantment that has filled the space of Rumi's poetry with its dazzling radiance. Elsewhere, Shams says: "Give your heart to heaven The path of the heavens is bigger, wider, softer and brighter, with the thought and temptation why one should be narrow and imprison the happy world "(Movahed, 1379: 180). In this position, he is even complex in a prophetic hadith and has criticized it: "I have not wrapped in any hadith of the Prophet (PBUH) except the hadith that" the world is the sanctuary of the believer "because I do not see any sanctity. "I mean, who is Sajan?" (Movahed, 1379: 181). And in another place he says: "I am amazed by this hadith that the world is the sanctuary of the believer that I did not see any sanctuary, I saw all the happiness, I saw all the honor, I saw all the friends" (Movahed, 1378: 182). He has analyzed this hadith in two other places and, of course, provides a justification for it. This love, passion, mood, ecstasy and joy, undoubtedly pervades the whole of Rumi's existence, to which he gives a famous love to the red-faced old man. He himself acknowledges that:

Shams Tabrizi is sitting as a king and my poem is lined up in front of him like helpless servants

(Rumi, 1345: 186)

The minutes of Shams' speech are as follows in the words of the Roman mullah:

Do not look at me from your weakness, look at you at night, look at me tonight 
On you, prison, on me, this prison is empty because the garden is my preoccupation

(Rumi, 1389: 2 / 3552-3553)

Khayyam's thoughts, if they lead to vulgar joys and pleasures and epicurean pleasures, such a meticulous mystical view lead to a kind of logical and wise happiness:

Whoever is not full of sorrow and sourness is not a lover of the province

(Rumi, 1345: 355)

If you are a lover, leave the sadness between the wedding and the mourning

(Rumi, 1345: 495)

To be sad at home is from your efforts, and in your heart, your secrets are like your efforts

Whatever trembles, he knows that the same currency of the saddle on the heart of the lover is more than the throne

(Rumi, 1345: 325)

Again, he describes this spiritual joy in a melodious language:

I do not eat sugar and sugar parrot, no matter how much I turn away from the sour world, I hate it.

If he made you sour, he gave me nectar and sugar, your hiccups and lameness from him, I am happy and away from him

Whoever does not go in this way is my valley and two-way house, from whom I will walk smoothly in this path.

The mosque is the end of my heart, the paradise of my heart has been enlightened, including my works from him

Whoever laughs at his right, laughs out of his mouth. If you deny him, I all confess to him.

The part of the flower was laughter

(Rumi, 1345: 465)

The wind blows the sad ones and we are happy to face the prisoners with the grief of our ten opioids.

Our blood on forbidden sorrow and the blood of sorrow on us became lawful for every sorrow that surrounded us in its blood

(Rumi, 1345: 267)

\section{.Liveliness of choice}

Rumi is an independent poet, unlike Hafez, who is a complex poet in the plant of algebra; Rumi, in a beautiful and heartfelt interpretation, considers the burden of trust as "discretion" that man has voluntarily borne on his shoulders the great burden in disbelief of the heavens, the earth and the mountains, and the guardian of the madman who unwittingly and forcibly draws the unknown trust fortune Have been numbered in his name. Rumi has chosen himself and he has chosen and Hafez has been chosen. Hafiz is an infected cage that, although he is not hated by the Congress of Thrones, is still a parrot behind the mirror of the universe; But Rumi is a 
talkative parrot who escapes from the prison of humiliation and flies to India, and escapes from the prison of predestination, boredom and hardship!

The prevalence of the deterministic ideas of the Ash'arites, from the second to the ninth centuries, placed many poets and writers called Iran in the dominance of algebraic thought; Know that even dignitaries such as Ferdowsi, Saadi and Hafez did not escape from this narrow and dark circle. There are many poems and writings among the many poets and writers who have reflected on deterministic thinking over the centuries, which is a clear proof of our claim. Of all the famous poets of the last few centuries, perhaps only Rumi can be mentioned explicitly, who has always distanced himself from this narrow circle of deterministic thinking. Nearly two thousand verses of the spiritual Masnavi are devoted to proving authority, and Rumi, in places of his mystical masterpiece, explains this wide-ranging story and in every possible way rejects the theories of domination and despair of coercion. Rumi, by recognizing the aspects of matter and awareness of various philosophical and theological ideas, proves human free will. From this point of view, Rumi seems to be a unique poet. Even when he succumbs to voluntary algebra in the realm of mystical thought, not only does a handful of his enthusiasm not diminish, but he leaves the subject to his friend more eagerly and politely than before, and in his venerable poems with Reflects his eager and expanded soul. According to the transcendent belief, the mystic, in a degree of conduct, reaches the position that he ignores the will and desire of the part in comparison with the total providence, and again eagerly and voluntarily submits to another kind of algebra which he calls his mystical algebra (cf. Khaghani, 1389: 17). Although, in his perfectly reasoned opinion:

This is not algebra, this means coercion

(Rumi, 1389: 1/618)

The existence of such precise and deep and at the same time active and motivating thoughts and ideas, turns Rumi into a poet full of passion, passion, turmoil, intoxication and love, who does not stop in front of his eternal lover and is fascinated. AH and depicts his ecstasy and enthusiasm in the words of the song and melody. This unwavering freedom and liberation of the soul sometimes even takes him away from the monopoly and narrowness of the rhyme, as if he thinks beyond the worries of speech, voice and speech, listening to the eternal soul.

I will stir the words and the speech so that I can breathe with you without all three of them

What was the word to make you think of what the word was?

Rumi, 1389: 1 / 1252-1253)

From this point of view, Rumi is clearly different from the poets of his class, and this difference pours indescribable, astonishing and different joy in his words, which after several centuries, by reading his audible sonnets, this ecstasy is broken. And the failure of time brings itself to the sad and sorrowful man of the ages.

Thank you, thank you, thank you, I'm thankful for your advice, I'm passionate about it

It is a house of happiness, my heart, I am not sad, what should I do? Whatever I do in the sour world, I hate it

When did I take it with me? Who? I give flowers on my head in May, my nightingale flowers on it

I'm happy and you're half happy, try to taste until you get a cup, because I'm caught

(Rumi, 1345: 496) 
In this noble poem, Hazrat Maulana depicts his views on how and why happiness and sorrow are so beautiful:

Jannati made the world laugh with gratitude who taught me to laugh like sugar

Although I was born out of unhappiness and smiling, love taught me to laugh differently

I stay in the oyster, I laugh when they break me, it was Khaman's job to laugh at Fatah and Zafar

One night he came to my trust and taught me to laugh like a dawn every morning and morning.

If it was sour on my cloud, my smile was a lightning habit when I laughed

If you die sooner, you will borrow money and laugh at the crown and the back

Verto Jesus, an adjective? Eunuch! Learn from Azo about the sorrow of lust and about laughter between men and women

$\mathrm{O}$ astronomer, if you believe in the moon, you should laugh at yourself and the sun and the moon

Laugh like a bud in secret and do not laugh like a candle when it blooms at the top of a tree...

(Rumi, 1345: 554)

\section{Factors of happiness}

Among the factors that create happiness, we can name the cultivation of positive mental states such as: compassion, compassion, forgiveness, forgiveness, empathy, etc., which cause spiritual happiness and expansion of the human mind. Also, having welfare facilities, wealth, fame, status, beauty and children, can cause a feeling of happiness and satisfaction in human beings. But all these cases and similar examples are the joys of this world and transient, and they are subject to destruction and annihilation at any moment. Our actions are the result of our thoughts and ideas, so obviously if we have positive and happy thoughts, we will be happy in our lives as well. "At the same time, seeing the truth causes happiness, joy and hearing." (Ebrahimian Amoli, 1378: 561) Happiness in Rumi's Masnavi is psychic and inner; He abandons humble social attachments and sweetens the bitterness of selfishness and immaturity by observing Jamal Jamil Yar.

Rumi considers the beloved to be the main factor of happiness and the lover finds himself happy because of his closeness to this great and eternal power, and this kind of happiness is beyond any kind of fleeting superficial happiness. Material joys are different from real and spiritual joys. The joys of this world, because they come from fleeting worldly and sensual pleasures, are like wounds that can only be healed with the ointment of sorrow. In contrast, there are great and lasting joys that never turn into sorrow. They are like gifts from the unseen world. He believes that if you want happiness to be lasting and permanent, it must boil from within, and the source of that joy must be the human heart, in other words, "the joys that come to man from the outside will perish after a while and be replaced by sorrow and grief." "They are depressing." (Sadeghi, 1386: 80) There are those who do not know that the factors of happiness always wave inside and around them and in vain eat the sorrow and grief of the times and engage themselves in things that have no real value and waste valuable life at the feet of absurd factors. Therefore, "If a person is not a follower of greed and does not constantly miss the lives of others, and instead seeks to satisfy his conscience and sense of humanity and becomes accustomed to seeing the beauties of the world, he will not only enjoy the happiness and well-being of others but also Seeing the shining sun and the blossoming of the flower and the smile of the child, will make you feel a world of happiness, if all the angels of heaven try to make your heart happy, so that 
you do not want to know what happiness is and what you do not want to be happy. (Kasmaei, 1356: 102).

All these sorrows that are in our hearts are from the steam and the wind and our existence

This sadness is our obsession with "this is how it was and so"

(Rumi, 1389: 1 / 2297-2296)

\section{Manifestations of joy and sorrow}

The mystics of the Divine Gate in their journey and conduct, suffer from convulsions and inner and inner openings of mind, which in the beginner seeker, fear and hope, and in the intermediate seeker, the contraction and expansion, and in the perfect and the ultimate, are called awe and humility, which of course The subject and the quality are very different from each other, and these categories cannot be considered close to each other, although in appearance they are similar They are together. Happiness and apparent sorrow is to lead a person to spiritual joy and sorrow, and in the words of Rumi: but a role

Wayne sadness and joy that is in the heart of the line before that joy and sorrow is nothing

A smiling face plays a role in your face so that it becomes the correct meaning

(Rumi, 1389: 1 / 2769-2768)

The state of happiness in human beings, as it can be seen, can be expressed with a burning face, joy and laughter, and sadness can be compared to the enemy of life and sickle, which can be accompanied by sadness, frustration and crying. The issue of happiness as one of the basic human needs and an influential element has always been considered by religious leaders. So that Imam Ali (AS) has interpreted this emotional state as "opportunity". "Hazrat said:" Happiness is an opportunity, it means an opportunity to gain more ability and vitality. " He considered one of the attributes of the believers to be a happy face and said: "The believer is human in his face and sad in his heart; The joy of the believer is in his face and his sorrow is in his heart "(Razi, 1388: $515)$.

In Rumi's view, crying is a manifestation of sorrow and boredom. In his view, if crying does not arise from human knowledge, it is a sign of weakness and weakness. In fact, crying, the appearance of sorrow and laughter on the outside face is joy and happiness. "Passivity and influence stem from defect and weakness. A Sufi must be strong and above the influence and possession of foreign affairs, and it must be such that he himself influences things and, for example, is joyful and not joyful. "The source of all pleasures and joys is the human heart." (Kaymanesh, 1366: 743). Sadness and joy inside a person ند like two scales are always fluctuating and going up and down. Just as balance cups are on the same level when they are normal and empty and are equal to each other, so if one of the cups becomes heavy, the balance of the cups will be disturbed, similar to the situation in Man is also honest, so that the more and more intense our attachments and attachments to the world and material things become, the greater the distance between us and our eternal lover. Therefore, the amount of two cups of sorrow and joy will go up and down inside us, and this fluctuation will cause our sadness and despair.

\section{The effects of joy and sorrow}

Following the emergence of two senses of joy and sorrow in human beings, their effects can be seen in the appearance and interior and in the face, speech and actions of people, and from these effects, their inner states and individual characteristics can be traced. win. The effects of happiness include mental health and physical health, health and well-being of those around them 
and social security, economic growth and individual spiritual growth and spiritual growth of those around them, as well as the strength of the family system. Happiness not only affects the soul and psyche of man, but also affects his body. As they have said: it is even able to prevent the growth and development of cancer and mental illnesses and treat them. Humans leave out that the main social effects of grief, perversion and mistreatment of others can be enumerated. As Rumi has pointed out, a Sufi must be such that external events do not affect his heart and soul. By analyzing sorrows and joys, one can measure the personality of human beings and in fact it can be said that everyone's personality depends on his sorrows and joys. Thus, sorrows and joys directly affect a person's personality and psyche and overshadow his life. This type of grief can be called positive grief, not negative grief that arises from feelings of guilt, selfishness, suffering and worldly desires and worldliness (cf. Karami, 65). While positive grief is rooted in being away from the beloved, in other words, joy and sorrow are either sensory (receipt) or spiritual (expansion). According to Rumi:

Grief at the behest of the Creator, came the staff

(Rumi, 1389: 1/837)

or:

Because he wants to be happy with the same sorrow and freedom

(Rumi, 1389: 1/838)

Certainly, from time to time, human beings will grieve and cry because of committing various sins. But this weeping and remorse is like the weeping of the spring, which causes the earth to prosper and green, and it will irrigate the garden of life.

I will make the soil of sorrow crimson for each eye until the gem of two eyes is filled

Tears are the essence of creation and tears are thought to be creation

(Rumi, 1389: 1 / 1780-1781)

The tears shed in sorrow and grief are as precious as the blood of the martyrs. Grieving for God's sake is like a garden in which, in the end, the "sugar of happiness" will grow. Provided that man embraces sorrow with love and considers it as a faithful and trustworthy friend. As Rumi said:

The sugar of happiness is the fruit of the garden of sorrow. This joy is a wound and that sorrow is an ointment

(Rumi, 1389: 3/3752)

Dr. Eric Lindman, an American physician and psychologist, based on the experience and experiments he performed during the treatment of hundreds of his patients in one of the most famous American hospitals, came to the conclusion that: If someone suffers from grief and grief, it The so-called famous pour in his heart and does not express his sorrow and grief in the form of crying and other common forms such as: pain and heartache with those around him, reciting prayers, etc. Finally, this sorrow and grief stored in his heart in the form of illness or The reaction to the disease appears and manifests itself. Sometimes the diagnosis and treatment of the disease is difficult. In confirmation of this matter in the book "Psychology in the service of human beings" it is stated: "When These mental patients succeeded with the help of a psychologist. To express the hidden effects of grief and sorrow in their hearts and to find an opportunity to express it. The healing they received from their mental illness was so strange and sudden that you said they had never had such sorrow. In short, new topics in psychology consider it necessary to express sorrow and not to sink into grief in order to be safe from mental illness "(Kasmaei, 1977: 145-144). 


\section{Conclusion}

The existence of sorrow and happiness in human beings is necessary and inevitable, and what is important is to direct these two categories on the one hand and to put each in its place on the other. According to Rumi, sorrows and tears are divine ambassadors, some of which are the result of human sins and disobedience. According to religion, worldly sorrow must be interrupted, and if it is transmitted to the face and is permanent, it not only intensifies sorrow, creates despair and despair, but also causes sorrow and grief to others. Sorrows are the basis of joys. Some grips and entanglements are the basis of new openings and expansions in life. One of the existential philosophies of sadness and happiness is to make life more beautiful. Sadness and happiness are two opposites that both depend on understanding each other. One can understand the joys of the world that one has experienced sorrow so that there is no sorrow and there is no joy. Sadness and happiness are two human phenomena and are inseparable from human beings and encompasses all human beings from greatness and knowledge according to their spiritual requirements. Rumi's pain and sorrow are in conflict with the known human pain and sorrow. On this basis, it can be said that Rumi seeks sorrow to release him from sorrow.

Always sadness قابليت in Rumi's mind has the ability of devotion, which is happier than happiness. In his opinion, sadness and happiness are inseparable. Rumi is a happy and popular poet and sadness and sorrow in his view is an evolutionary process from the lowest level to the highest degree. In his view, sorrow is one of the tools of conduct, and the seeker cannot be painless and sorrowful. Therefore, sorrow and joy cause human mental moderation. Wise sorrows should be welcomed and irrational joys should be avoided. Wise sorrows are the way to happiness, and as a result, the dynamism and mobility of the soul destroys many of the sorrows and daily joys and gives the soul its true purity.

\section{References}

- Ebrahimian Amoli, Seyed Yousef (1378); Aftab Erfan, Thematic Guide to Rumi's Masnavi, Volume I, Amol: Author.

- Jafari, Mohammad Taghi (2000) Rumi and Worldviews, Tehran: Allameh Jafari Publishing House

- Khaghani, Mohammad; Davood Nejati; Reza Jafari (2010) Journal of Mystical Literature Research, No. 2, Article: Algebra and Authority in Hafez and Ma'ari Worldview, Isfahan: University of Isfahan.

- Razi, Seyed Sharif (1388); Nahj al-Balaghah, translated by Professor Mohammad Dashti, Tehran: Payam.

- Mathematics, Heshmatullah (1385); Spiritual stories and messages, by Habibollah Pak Gohar, Tehran: Haghighat

- Zarrin Koob, Abdul Hussein (1382); Broken Ladder, Descriptive and Analytical Description of the First and Second Books of Masnavi, Tehran: Sokhan.

- Soroush, Abdolkarim (2001) The story of the Lord of Knowledge. First Edition, Tehran: Sarat

- Sadeghi Hassanabadi, Majid (1386); Article on Sadness and Happiness in Rumi's Religious Experience, Faculty of Literature and Humanities, University of Isfahan: No. 49

- Ghasemi, Nizamuddin, Qureshian, Marzieh (2009) Article (Positive Psychology, a New Psychological Approach to Human Nature », Quarterly Journal of Psychotherapy, No. 51 and 52 - $98-114$

- Karami, Reza Ali (2015) Happiness in the Islamic lifestyle, Tehran: Qalamgah. 
- Kasmaei, Ali Akbar (1356); Psychology in the service of humanity, Tehran: Gutenberg.

- Kaymanesh, Abbas (1366); Parto Erfan, Explanation of Mystical Terms in Generalities of Shams, Tehran: Skills

- Gerson, Max (2007) Cancer Therapy, (Translation: Seyed Mashallah Farkhondeh), Tehran: The New Thought Generation

- Matthews, Andrew (2007) The secret of living happily, (Translator: Shahriar Ghaderi), first edition, Tehran: eyelid.

- Movahed, Mohammad Ali (1379) Shams Tabrizi. First Edition, Tehran: Sarat

- Rumi, Jalaluddin Mohammad Ibn Mohammad (1345) Generalities of Shams, (corrected by Badi'at al-Zaman Forouzanfar), Tehran: University of Tehran.

- Mawlawi, Jalaluddin Mohammad Ibn Mohammad (2010) Masnavi Manavi, according to the revised version of Rinwald Nicholson, Tehran: Milad.

- Mir Shah Jafari, Ebrahim Abedi, Mohammad Reza, Drikundi, Hedayatullah (2002) Article (Happiness and Factors Affecting It) Cognitive Science News, Fourth Year, No. 3 - 50-58.

- Hadfield, J. A (1374) Psychology and ethics, scientific translation of Parivar, Tehran: scientific and cultural, third edition 